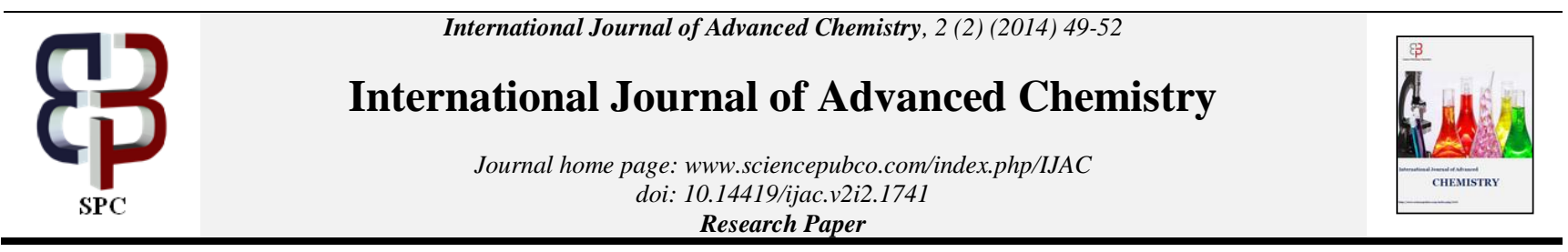

\title{
Performances of electrodialysis process in desalination of brackish waters at various salinities and voltage
}

\author{
F. Elazhar ${ }^{1}{ }^{*}$, M. Elazhar $^{1}$, M.Hafsi $^{2}$, M.Taky $^{1}$, A. El Midaoui ${ }^{1}$ \\ ${ }^{1}$ Laboratory of Separation Processes, Department of Chemistry, Faculty of Sciences, Ibn Tofail University \\ ${ }^{2}$ National Office of Drinking Water and Electricity (ONEE), Rabat, Morocco \\ *Corresponding author E-mail: azh80ar@yahoo.fr
}

\begin{abstract}
In the south Mediterranean countries and especially the North Africa, the water demands, since many decades, have increased while the conventional water availability has decreased dramatically. These trends continue. The obligation to use other non-conventional water resources such as desalinating water or waste water reuse becomes a necessity.

Electrodialysis is a membrane process that competes with reverse osmosis for desalination and the removal of specific inorganic contaminants

The experiments for desalination were carried out of various synthetic brackish waters containing 2, 4, 6, 8 and $10 \mathrm{~g} / \mathrm{l} \mathrm{NaCl}$ in order to determinate the operating conditions of electrodialysis process. The pilot used supplied by the Tokuyama Corp. The influence on the desalination performances of many running parameters such as voltage and salinities was investigated.

These studies demonstrated that the electrodialysis is an effective method of being used to desalinate brackish water was well as water with higher salt concentrations up to about $10 \mathrm{~g} / \mathrm{L} \mathrm{NaCl}$.
\end{abstract}

Keywords: Electrodialysis, Performances, Membrane, Voltage, Salinities, Intensity.

\section{Introduction}

The shortage of drinking water is a major problem in the southern communities of Morocco. In these regions, the precipitations are insufficient to meet the demand for water and it is, therefore, necessary to resort to underground resources. However, the salinity content of these aquifers is largely exceeded the acceptable standards of drinking water.

Electrodialysis is one of the membrane processes that proved reliable and efficient in many application especially the production of drinking water from brackish and seawater[1], [2], also the treatment of industrial effluents [3], [4], the recovery of useful materials from effluents and salt production [5], [6] The basic principles of ED have been reviewed in the literature [7]. Figure 1 shows the charge transport in a conventional electrodialysis system for $\mathrm{NaCl}$ solutions. The ionic separation in this process takes place under the effect of an electric field. [8], [9].

The focus of the present study is to determine the performances of ED for the desalination of synthetics brackish waters containing a various salinities of $\mathrm{NaCl}$. The removal of the chloride and the sodium were carried out under various running conditions such as the applied voltage and the initial salt concentration.

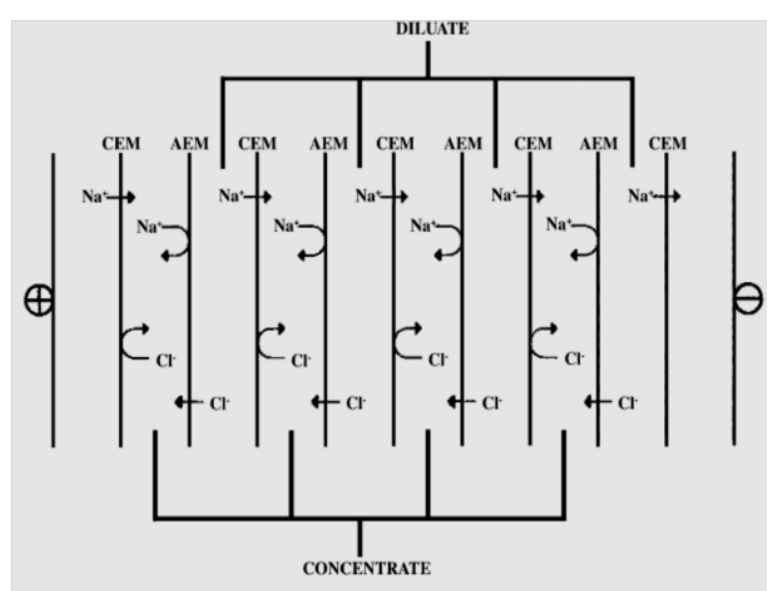

Fig. 1: Charge transport in the electrodialysis stack.

\section{Materials and methods}

\subsection{Electrodialysis plant}

The electrodialysis operation was carried out on a laboratory pilot plant (figure 2). This apparatus was a batch electrodialysis unit composed of ten compartments alternatively separated by cation and anion exchange membranes. The two electrode compartments are separated from the others to prevent a modification of the composition of the solution, which could be caused by electrode reactions. The circulation of water through the dilute, concentrate and electrode rinse compartments was assured by pumps. The used membranes were a conventional cationic exchange mem- 
brane CMX and an anionic exchange membrane AFN manufactured by Tokuyama Corp. The stack design characteristics of the electrodialysis pilot plant are given in Table 1 .

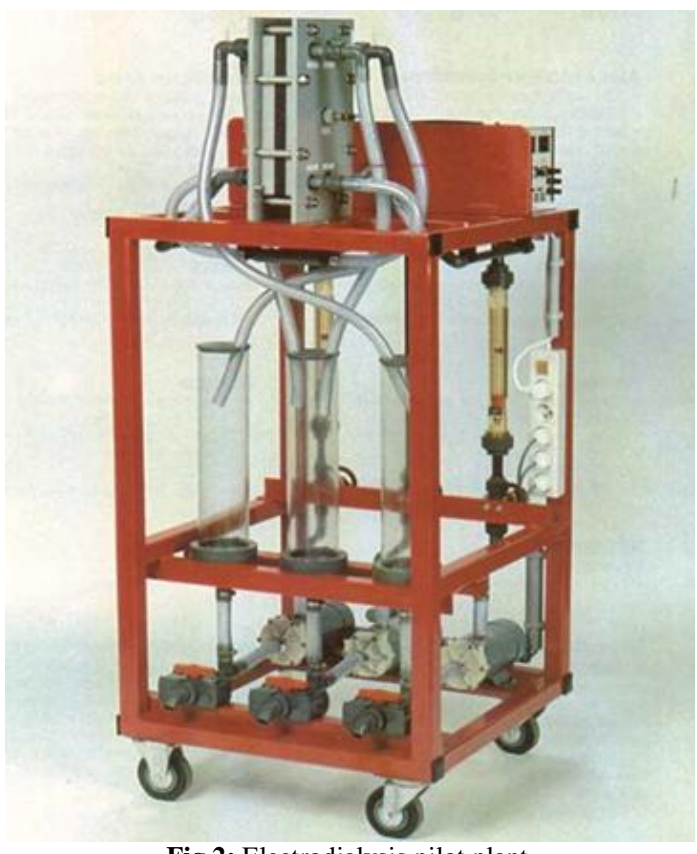

Fig 2: Electrodialysis pilot plant

Table 1: Stack design

\begin{tabular}{ll}
\hline Membrane area $\left(\mathrm{cm}^{2}\right)$ & 200 \\
Cation exchange membrane & $\begin{array}{l}\text { CMS Tokuyama } \\
\text { Corp. }\end{array}$ \\
Anion exchange membrane & ACS Tokuyama Corp. \\
Number of cell pair & 10 \\
Separator & PE + PP \\
Electrode & DSE \\
Flow of dilute and concentrate compartments & $180-200$ \\
(1/h) & \\
Flow of electrode compartment $(\mathrm{l} / \mathrm{h})$ & 150 \\
Current max $(\mathrm{A})$ & 9 \\
Maximum voltage $(\mathrm{V} / \mathrm{Cell})$ & 1.5 \\
Polarity Reversal & Manual \\
\hline
\end{tabular}

To prevent the scaling and fouling membranes, the polarity of the direct current was reversed at the end of each test, and the stack was flushed periodically with an acidic solution.

\subsection{Characteristics of feed water}

The experiments were carried out on synthetic water prepared from distilled water doped with $\mathrm{NaCl}$ at various concentrations: 2, 4, 6, 8 and $10 \mathrm{ppm}$. Table 2 gives the characteristics of the feed water.

Table 2: characteristics of the feed water

\begin{tabular}{lllll}
\multicolumn{5}{c}{ Table 2: characteristics of the feed water } \\
\hline Salinities $(\mathrm{g} / \mathrm{l})$ & $\mathrm{pH}$ & $\chi(\mathrm{mS} / \mathrm{cm})$ & $\mathrm{Cl}^{-}(\mathrm{ppm})$ & $\mathrm{Na}^{+}(\mathrm{ppm})$ \\
\hline 2 & 6,19 & 4,01 & 789,87 & 1203,58 \\
4 & 6,02 & 7,82 & 1464,37 & 2482,396 \\
6 & 6,3 & 11,4 & 1908,12 & 3272,22 \\
8 & 6,44 & 14,98 & 2440,62 & 4983,59 \\
10 & 6,62 & 18,46 & 3017,5 & 5641,8 \\
\hline
\end{tabular}

\subsection{Analytical methods}

During the tests, water samples are taken periodically and the ion concentrations were determined analytically. The content of sodium $\left(\mathrm{Na}^{+}\right)$and chloride $\left(\mathrm{Cl}^{-}\right)$were determinted analytically following standard methods [10], [11]. The values of conductivity $(\mathrm{mS} / \mathrm{cm})$ were converted to $\mathrm{NaCl}$ concentration from the following equation:

$\mathrm{NaCl}$ concentration $(\mathrm{ppm})=\frac{E C \times 89.4}{1.8}$
With:

EC: Electrical conductivity $(\mu \mathrm{S} / \mathrm{cm})$

The total energy consumption is the sum of energy applied to the electrodes and power hydraulic pump for circulating diluate, concentrate and rinse. The calculation of energy applied to the electrodes is determined by the following relation [12]:

$E_{\text {elec }}=V \times \sum_{i=0}^{n-1} \frac{I\left(t_{i}\right)+I\left(t_{i+1}\right)}{2} \times \Delta t$

With:

V : Applied voltage,

$\mathrm{I}\left(\mathrm{t}_{\mathrm{i}}\right)$ : intensity,

$\Delta \mathrm{t}$ : time (s).

The pumping energy is given by the following relation [12]:

$E_{\text {Pump }}=\frac{q \times \Delta P}{\eta}$

With:

$\mathrm{q}$ : flow rate $\left(\mathrm{en} \mathrm{m}^{3} / \mathrm{s}\right)$,

$\Delta \mathrm{P}:$ pressure $(\mathrm{Pa})$,

$\eta$ : Efficacity of the pump.

\section{Results and discussion}

In this work, the performances of electrodialysis membranes in salt removal are compared for various running conditions such as the initial salinities and of applied voltage. The studies were carried out on an industrial pilot plant.

\subsection{Influences of applied voltage on desalination}

In the first steep, desalination experiments using ED were undertaken to determine the performance of the system at three applied voltages; 5, 10 and 15 Volts and for a salinity of $6 \mathrm{~g} / \mathrm{l}$. Figures 3, 4, 5 and 6 give the variation of intensity, conductivity and $\mathrm{NaCl}$ concentration versus times for three applied voltage.

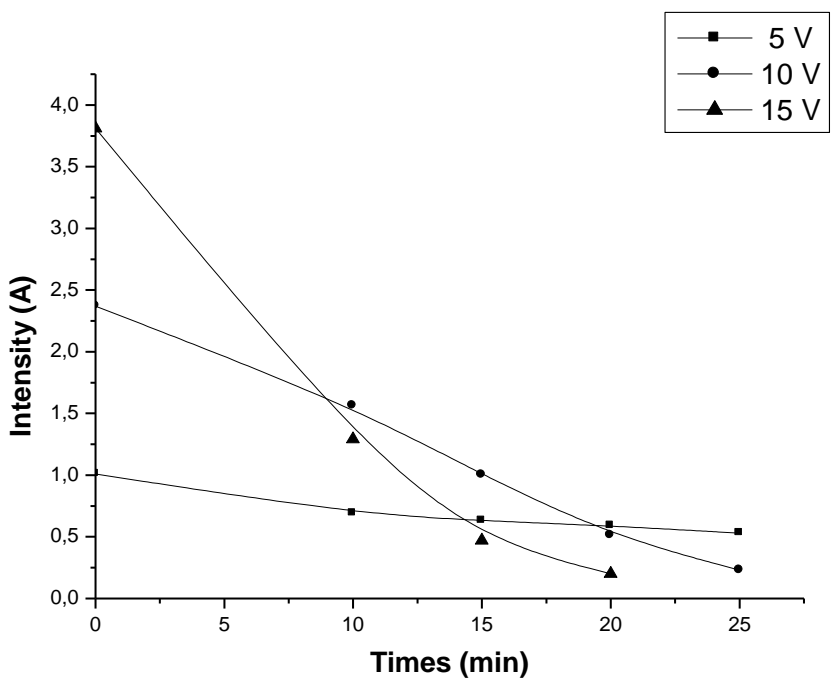

Fig. 3: variation of intensity versus time for three applied voltage 


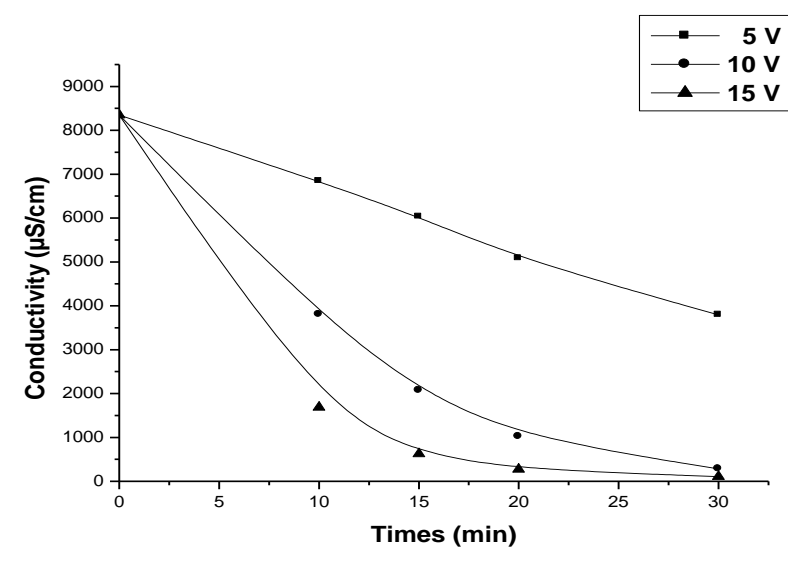

Fig. 4: variation of conductivity versus time for three applied voltage

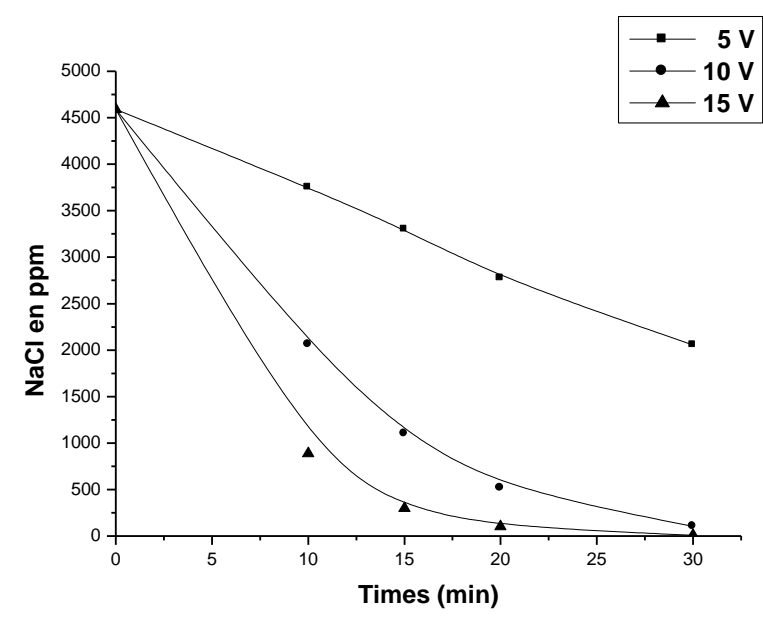

Fig. 5: variation of $\mathrm{NaCl}$ concentration versus time for three applied voltage.

The analysis of the results show that the intensity, the conductivity and the $\mathrm{NaCl}$ concentration in diluate compartment decreases within the initial $10 \mathrm{~min}$. After this point the decrease in salt concentration slowed down and an accompanying smaller incremental decrease in the current between the two electrodes within the stack was noted.

This can be explained by the phenomenon of the concentration and the polarization in the membrane boundary layer as well as depletion of electron carriers in the diluate. For desalination to occur in the electrodialysis there needs to be sufficient current between the cathode and anode.

Table 3: gives the evolution of demineralization energy, pumping energy and total energy consumption versus three applied voltage.

\begin{tabular}{llll}
\hline & $5 \mathrm{~V}$ & $10 \mathrm{~V}$ & $15 \mathrm{~V}$ \\
\hline Demineralization energy $\left(\mathrm{kWh} / \mathrm{m}^{3}\right)$ & - & 2.837 & 4.364 \\
Pumping energy $\left(\mathrm{kWh} / \mathrm{m}^{3}\right)$ & - & $610^{-6}$ & $610^{-6}$ \\
Total energy consumption $\left(\mathrm{kWh} / \mathrm{m}^{3}\right)$ & - & 2.837 & 4.364 \\
\hline
\end{tabular}

\subsection{Influences of initial salinities on desalination}

To study the impact of initial salt concentration the desalination process experiments were carried out with salt concentrations of 2 , 4, 6, 8 and $10 \mathrm{~g} / \mathrm{l} \mathrm{NaCl}$ at an optimum applied voltage of $10 \mathrm{~V}$. Figures $6,7,8$ and 9 give the variation of intensity, conductivity and $\mathrm{NaCl}$ concentration, energy consumption versus time for a different salinities.

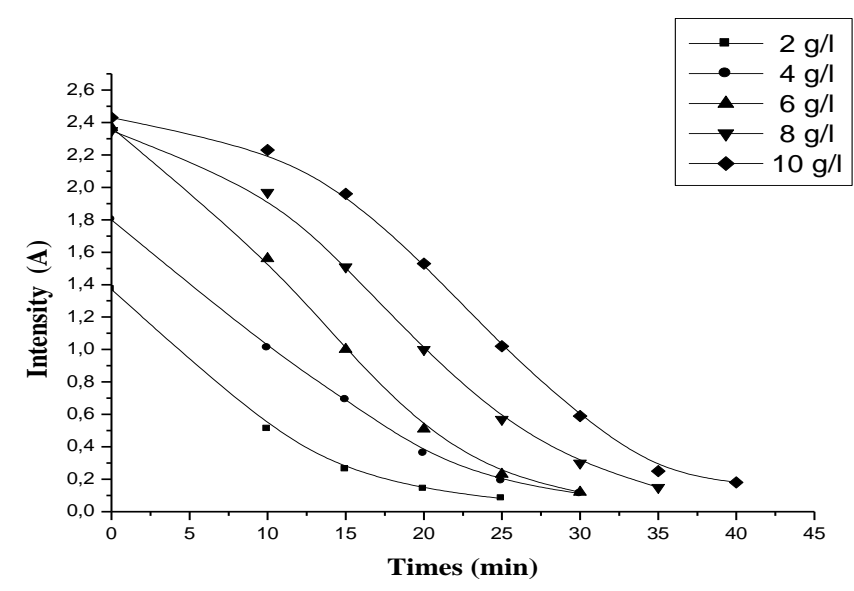

Fig. 6: Variation of intensity versus time for a different salinities.

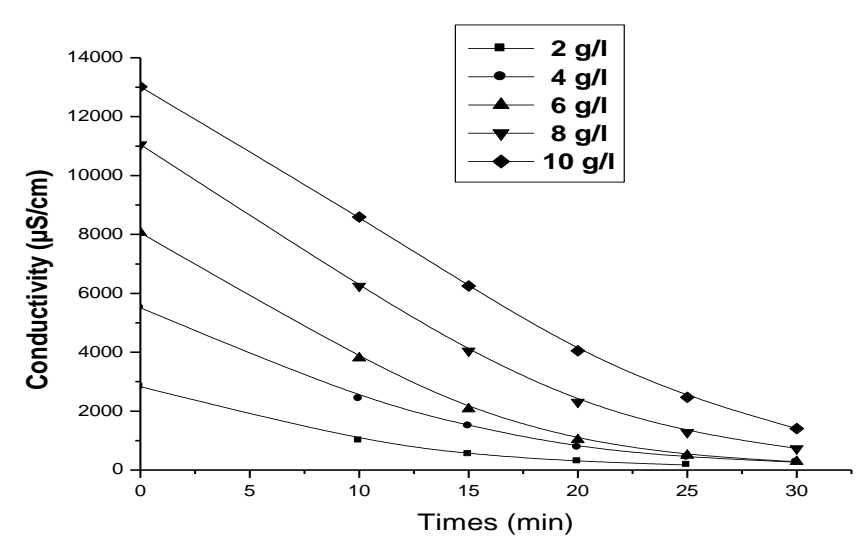

Fig. 7: Variation of conductivity versus time for a different salinities.

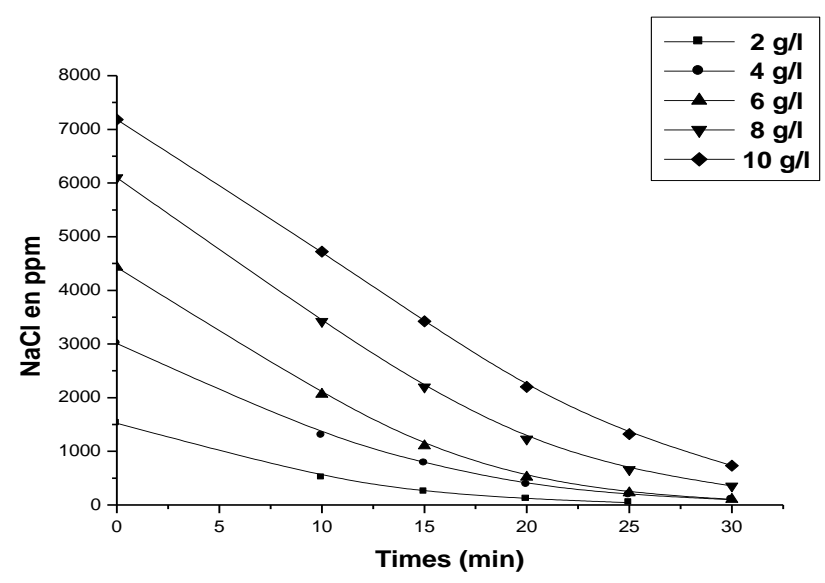

Fig. 8: Variation of $\mathrm{NaCl}$ concentration versus time for a different salinities.

For the different tested salinities. The several parametrs such as intensity, conductivity and $\mathrm{NaCl}$ concentration decreases versus time.

The $\mathrm{NaCl}$ guideline value for drinking water (500 ppm) was reached only in the experiments with an initial salt concentration of 2, 4, 6, $8 \mathrm{~g} / \mathrm{L} \mathrm{NaCl}$, but it was not reached with an initial salt concentration of $10 \mathrm{~g} / \mathrm{l} \mathrm{NaCl}$, however a removal of $97.5 \% \mathrm{NaCl}$ was achieved, after $30 \mathrm{~min}$ the desalination becomes marginal. Table 4 gives the values of time and the removal rate of $\mathrm{NaCl}$ for each tested salinities where the guide value of $\mathrm{NaCl}$ was reached (500 ppm). 
Table 4: Performances of ED processes at a various tested salinities.

\begin{tabular}{llllll} 
Initial salinities & 2 & 4 & 6 & 8 & 10 \\
\hline $\mathrm{NaCl}$ guideline $(\mathrm{ppm})$ & 500 & 500 & 500 & 500 & 500 \\
Times (min) & 10 & 17 & 20 & 30 & $\ldots$.
\end{tabular}

Removal rate of $\mathrm{NaCl}(\%)$

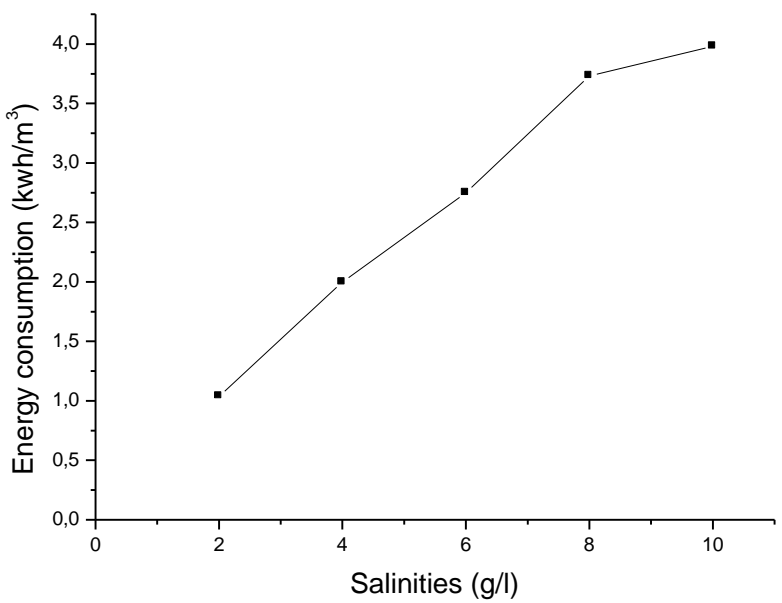

Fig. 9: Variation of energy consumption vesus time for a different salinities.

The analysis of results show that the energy consumption increases linearly versus salinities of up to $8 \mathrm{~g} / 1$, after this point the increase in energy consumption slowed forming a bearing. This can be explained with the phenomena of concentration polarizations in the membrane boundary layer. In this case the desalination becomes marginal.

\section{Conclusion}

The results of this study show that the electrodialysis is capable of being used to desalinate brackish water. However, for a lower concentrations of $\mathrm{NaCl}(2,4$ et $6 \mathrm{~g} / \mathrm{l})$, the reduction of $\mathrm{NaCl}$ is remarkable before $20 \mathrm{~min}$ in order to obtain the concentration of $500 \mathrm{ppm}$ of $\mathrm{NaCl}$ in permeate water (value declared in the drinking water standards). But for higher concentration of $\mathrm{NaCl}$ ( 8 and $10 \mathrm{~g} / \mathrm{l})$ the reduction of is remarkable that after $30 \mathrm{~min}$. Moreover, further work is required to determine fouling mechanisms for electrodialysis process.

\section{Acknowledgement}

This work was supported by Laboratory of Process Separation and ONEE (National Office of Potable Water and electricity) in Morocco. The authors express their thanks for this support.

\section{References}

[1] Maurel A., Revue Generale de l'Electricité 86 (1977) 6.

[2] Macedonio F., Drioli E., Compr. Membr. Sci. Eng. 4 (2010) 241-257. http://dx.doi.org/10.1016/B978-0-08-093250-7.00056-6

[3] Chon K., Lee Y., Traber J., von Gunten U., Water Research Volume 47, Issue 14, (2013) 5381-5391. DOI:10.1016/j.watres.2013.06.019

[4] Praneeth K., Manjunath D., Bhargava S.K, Tardioc J. S. S., Desalination 333 (2014) 82-91. http://dx.doi.org/10.1016/j.desal.2013.11.020

[5] Anh T.K., Tran Yang Zhang Nora Jullok Boudewijn Meesschaert Luc Pinoy Bart Van der Bruggen. Chemical Engineering Science, Volume 79, (2012), Pages 228-238. DOI:10.1016/j.ces.2012.06.001.

[6] Jiang C., Wang Y., Zhang Z., Xu T., Journal of Membrane Science Volume $\quad 450 \quad$ (2014) 323-330. http://dx.doi.org/10.1016/j.memsci.2013.09.020

[7] Ortiz J.M., Sotoca J.A., Exposito E., Gallud F., Garcia-Garcia V, Montiel V., Aldaz A., Journal of Membrane Science 252 (2005) 6575.DOI:10.1016/j.memsci.2004.11.021.
[8] Walsh F.C., A First Course in Electrochemical Engineering, the Electrochemical Consultancy, Hants, 1993.

[9] Pletcher D., Walsh F.C., Industrial Electrochemistry, Chapman and Hall, London, 1990.

[10]Elazhar F., Elamrani M., Taky M., Hafsi M., and Elmidaoui A., International journal of environemental sciences Volume 3(6), (2013) 2139- 2150. DOI: 10.6088/ijes.2013030600030

[11]Elazhar F., Tahaikt M., Zouahri A., Taky M., Hafsi M., and Elmidaoui A., World Applied Sciences Journal 22 (6), (2013)844-850. DOI: 10.5829/idosi.wasj.2013.22.06.268

[12]Lens P., Molenberghs B., Brauns E., Van Hoof V., Van Hoof E., Thomas G., Demey D., De Wever H., Dotremont C. Desalination 170 (2004) 123-136. http://dx.doi.org/10.1016/j.desal.2004.03.017 